\title{
Linguistic Peculiarities of Media Texts of Financial Sphere in the Social Media Space
}

\author{
Irina Malyavkina ${ }^{1}$
}

${ }^{1}$ Saint Petersburg State University

11 Lieutenant Shmidt Emb., St Petersburg, 199034, Russia

DOI: $10.22178 /$ pos.41-4

LCC Subject Category: PE1001-1693

Received 21.11.2018

Accepted 25.12.2018

Published online 28.12.2018

Corresponding Author:

irina_teletrade@mail.ru

(C) 2018 The Author. This article is licensed under a Creative Commons Attribution 4.0 License @ (1)

\begin{abstract}
The article is devoted to the linguistic peculiarities of media texts in the financial sphere focusing on the field of social media. Hereby we define two groups of lexical units that we are considering by media texts - characterizing lexical units and identifying lexical units. I also give here a detailed scientific description of each group composition, including examples taken from media texts. An integrated approach to the analysis of Russian-language and English-language media texts led to the conclusion about the most frequently used means of nominating realities, objects and phenomena in the sphere of credit and financial activity.
\end{abstract}

Keywords: media texts; financial sphere; social media; lexical units; financial discourse; language means.

\section{INTRODUCTION}

As a kind of institutional discourse by V. Karasik [2], the language of financial discourse (hereafter FD) by D. Kazyaev [3] has conceptual and semantic language means (terms), cliché and clericalism, sustainable use of a limited range of genrestylistic means, low contextuality, which are sometimes supplemented or replaced by individuality, expressiveness, metaphoricity of personalized language. Such heterogeneity is primarily due to the specifics of the financial and banking sphere (FBS) as a sphere of intellectual consumption, as stated by L. Shakiryanov [6]. This heterogeneity holds mostly intangible nature, which creates an obstacle in communication with the mass audience of the public. When the text reader in print media underestimate the low level of perception, it often leads to communicative failure L. Shakiryanov [8]. We experienced a similar situation in the framework of FD in the Russian print media in the period 2005-2012, up to the widespread of Internet communications and the appearance of the Internet as a new type of media - social media (SM).

The term social media is, first of all, understood as the type of mass communication via the Internet, as well as the whole range of the Internet sites which are based on online technologies, enable users to establish communication with each other and produce user-generated content or web resources created for users to communicate online, as stated by D. Scott [5].

Social media include Social networks; Blogs; Forums; Online personals; Wiki; Video hosting services; Social bookmarking etc.

Subjects of the financial and banking sphere most actively use social networks, video hosting sites, wikis, social bookmarks [5] to communicate with potential and real customers. The need to identify the linguistic features of media texts of the financial sphere in the social media is caused by the search for writing algorithms for media texts that positively affect the reader.

FBS media texts have a set of certain features which are explicated by specific verbal and nonverbal means. There are also some intra-text features which exist along with discursive features (the addresser and the addressee, the place and the time of the text, the intention of the addresser, the function of the text, the form and means of communication, the socio-economic context of communication, status-role, sociodemographic and cognitive-intellectual characteristics of the addresser and addressee). Intra text features are the subject, content, composition of the text, the method of organizing infor- 
mation, lexical and grammatical forms, syntax and non-verbal elements [7].

The last list makes it possible to identify the linguistic features of financial sphere media texts in the social media space.

However, until the beginning of 2010, scientists did not carry out any systematic philological analysis, considering media text as an integral multi-level construction in the inseparable connection of its verbal and media characteristics.

The modern linguistic concept allows to arrange a more comprehensive presentation of speech activity in the field of mass media [7], since it covers not only the message in addition to channel but also all the numerous extralinguistic factors associated with the creating characteristics of a media message, its recipient, feedback, culturing methods of encoding and decoding, as well as the socio-historical and political-ideological context. The analysis of the banking industry phenomena by T. Mahortova [4] was very useful in terms of the study of FBS media texts of social media and showed that banking articles mainly use non-terminological units of usual and occasional character. The positive connotation, neither usual nor occasional, characterizing nonterminological units suggests that these units serve to create an attractive image of a bank/insurance company in the mind of the addressee, they also form a psychological state of trust to FBS, i.e. they offer means for explication of the appealing installation of media texts [4].

\section{METHODS}

The most interesting part of media text study is an integrated approach, which is developed in the framework of media linguistics. In her latest publication in 2014 T. Dobrosklonskaya [1] lists a number of methods that underlie the integrated approach. It combines a wide range of methods from various disciplines and includes the following most significant and common groups of methods:

1. A group of linguistic analysis methods that allow identifying the basic properties and characteristics of the text at different language levels: lexical, syntagmatic (compatibility), stylistic (using tropes, comparisons, metaphors, and other stylistic techniques), sociolinguistics.

2. The method of content analysis, based on the statistical calculation of specially selected text units.
3. The method of discursive analysis, based on the concept of discourse which allows tracing the relationship between the linguistic and extralinguistic side of the text.

4. The method of critical linguistics, which allows revealing the hidden political-ideological component of the media text. It is based on the identification of the evaluation, reflecting certain ideological views and attitudes of components.

5 . The method of cognitive analysis, based on the study of the conceptual aspect of media texts, which is also based on a comparison of various interpretations of events in the media and aimed at identifying the relationship between the reality and its media presentations.

6. The method of linguo-culturological analysis, based on identifying culturally significant components of the text, such as realities, lexical borrowings, foreign words, units of unequivocal vocabulary, etc., allowing us to get an idea of the cultural aspect of media life or its cultural identity.

7. And finally, the media linguistic method, which involves text analysis in terms of a stable system of parameters for describing a media text, such as the way it was created and reproduced, the distribution channel, the functional-genre type, the thematic dominant, etc. The scientific description of the above-mentioned methods allows us to analyze the empirical base and offer our methodological recommendations on the use of linguistic factors of influence during the creation of media texts in the framework of financial discourse.

\section{RESULTS AND DISCUSSION}

The empirical base of the research includes more than 100 media texts (total amount of 21,200 words) published on the pages of FBS (banks and insurance companies registered in the Russian Federation - Alfa-Bank, Rosbank, Rosgosstrakh, Ingosstrakh, Renaissance Insurance, Insurance House, RESO Guarantee, SOGAZ in social networks Vkontakte, Facebook, YouTube, as well as in FBS English-language media texts UP Morgan Chase, Bank of America, Citigroup, Goldman Sachs Group, Morgan Stanley, Wells Fargo) and the UK (Lloyds TSB) on the popular US electronic resources Pinterest, Khan Academy, VICE News.

Verbal explication and communicator intentions in the texts of FBS placed in social media are carried out by using appropriate lexical, morpho- 
logical and syntactic means. According to the totality of the main features, the lexical units used in SM texts are divided into two groups: 1) characterizing lexical units; 2) identifying lexical units.

1. Characterizing lexical units (CLE) are content words and phrases with nominative sense; they usually work as names of realities, objects, and phenomena in the field of financial activity. CLE presented in SM include integral terminological units and heterogeneous verbal signs of a terminological and non-terminological nature, performed by various structural types of word combinations.

1.1. Terminological units are represented in media texts by specialized terms of the credit and financial sphere of communication, which serves as a transfer for specifics in banking and insurance activities and general economic terms used in various spheres of economic communication. These units also work to express the general economic conditions for describing functions of FBS, for example, international transfers, Internet banking, Internet platform, clients, funds crediting, currency conversion, recipient's account details, etc.

According to system-normative basis, we can define terminological units by the usual and occasional approach. The usual terminological units are stable, generally accepted and unified. They are fixed in dictionaries in accordance with the language unit norms for example franchise, futures, etc. These units are a minority out of the total number of terms in the SM texts.

Terminological units with the occasional nature, which as for now are not generally accepted, are characterized by individuality and unique reference. They are determined by the specific context of use and are built mostly on non-standard nomination models, for example, Alpha-Click, Alpha-Mir, etc.

Occasional terminological units have a nominating function. They perform as the primary and fatal function and deal with implicit activation of the reader's emotional reactions. Thus, these units exist as a means of identifying the subject of FBS and its aim is to attract the attention of the addressee. In the case of social media space - to draw the attention of group members to a particular service.

Not only the semantic-communicative specific of terminological units is casual, occasional nature determines their role in the explication of an informative text installation.

These specifics main points are its accuracy, economy, stylistic neutrality, mono-semantics, and precisely defined reference.

1.2. Heterogeneous non-terminological nominative units are also a part of the group of characterizing vocabulary along with integral terminological units. They consist of phrases that include the semantic dominant as a constant component (C) and determine its variable (V), i.e. variable component. The constant component is represented by a terminological / non-terminological unit, and the variable component is represented by various model types, for example, a unique (V) Internet platform (C); instant (V) crediting (C); key (V) advantage (C), etc.

Since the structure of the given heterogeneous signs contains a variable component, which can be replaced by any other component, these signs do not have a specific terminological nature. Thus, when we determine the constant (technical term), the terminological unit does not lose its semantic content, but as a characterizing unit in combination with the determining variable is not a term, in contrast to terminological phrases.

When we are talking about system-normative characteristics we can name two heterogeneous characterizing non-terminological units: casual and occasional. Characteristic non-terminological units of a usual nature are generally accepted and are built using usual terminological / nonterminological units and lexical units of positive expression, for example, Apple Pay is much better than a regular contactless payment card.

Characteristic non-terminological units of an occasional character are phrases that include an occasional constant component, which means a unique (single) substantive essence, and a usual variable component denoting a sign of a permanent component, for example: When you are the fastest, the biggest remains to catch up with you. Today only two banks have connections between Visa cards and Apple Pay. The use of such units is limited by a small context, i.e. by FBS official page on the social network.

2. Identifying lexical units (ILU) are proper names expressed by a word or a word combination. Their main function is to distinguish an object named by them among the number of similar ones, individualizing and identifying this object. 
These lexical units are usually on a systemnormative basis proper names which possess mono-semantic correlation with special and unique objects or phenomena of reality are presented in the following types of media texts:

- the name of the bank / insurance company that has the official page in the SM, which is used both to inform about the addressee and to fix the FBS image in the mind of the addressee with regular frequency of its name throughout the text, for example: Alfa-Bank Russia, IC Rosgosstrakh , Citibank and others;

- names of partner institutions of the addressor (well-known banks, investment, and insurance companies) that helps to create an image of a solid and reliable bank, for example, AEG, Visa, Apple Pay, etc.

- the names of companies providing information to the addressee (for example, rating agencies), the use of such companies serves to convince the addressee in the accuracy of the information presented, for example, Standart \& Poors and others.

When proper names describe objects they identify and distinguish them from a number of simi- lar ones and thus actualize the informative and appellative intentions of the media text.

\section{CONCLUSIONS}

Thus, the most commonly used tools for the nomination of realities, objects and real phenomena in the media texts of credit and financial sphere are non-terminological word combinations of the usual character and specialized usual terminological units expressed by complex nouns. In order to emphasize the uniqueness of the banking/insurance services, the addressees use the terminological units of the occasional nature in the form of complex nouns, as well as non-terminological phrases of the occasional nature.

\section{ACKNOWLEDGMENTS}

Given article was translated thanks to Aleksei Rumynatsev (Diploma in Linguistics) SaintPetersburg, Russia.

\section{REFERENCES}

1. Dobrosklonskaja, T. G. (2014). Medialingvistika: sistemnyj podhod k izucheniju jazyka SMI. Sovremennaja anglijskaja mediarech' [Media linguistics: a systematic approach to learning the language of the media. Modern English mediarech]. Moscow: FLINTA (in Russian).

2. Karasik, V. (2000). Struktura institucional'nogo diskursa [Institutional Discourse Structure]. In Problemy rechevoj kommunikacii (pp. 25-33). Saratov: Izd-vo Saratovskogo universiteta (in Russian).

3. Kazyaev, D. Y. (2015). Translation strategy of texts of the german financial discourse (based on material of banking brochures). Humanities scientific researches, 4. Retrieved from http://human.snauka.ru/en/2015/04/10881

4. Mahortova, T. (2007). Lingvopragmaticheskij potencial PR-zhanra v prostranstve bankovskogo diskursa: na materiale nemeckojazychnyh bankovskih prospektov [Linguopragmatic potential of the PR genre in the space of banking discourse: on the material of German bank prospectuses] (Doctoral thesis). Retrieved from http://www.volsu.ru/download.php?id=e42bb96c\%2042de\%2011e3\%207580\%200025909a cda2-1.pdf (in Russian).

5. Scott, D. M. (2017). The new rules of marketing \& PR: How to use social media, online video, mobile applications, blogs, news releases, and viral marketing to reach buyers directly. Hoboken: John Wiley \& Sons, Inc.

6. Shakir'janov, L. (2013). Jekonomicheskij diskurs i finansovyj diskurs Bloomberg i Reuters [Economic Discourse and Financial Discourse Bloomberg and Reuters]. European Social Science Journal, 38, 210-218 (in Russian).

7. Shakir'janov, L. (2013). Medialingvistika: jekonomicheskij aspekt [Medialinguistics: economic aspect]. European Social Science Journal, 35, 202-207 (in Russian). 
8. Shakir'janov, L. (2014). Logiko-semanticheskaja kategorija kontrasta v finansovo-jekonomicheskom media-diskurse (na materiale anglojazychnyh internet-istochnikov) [The logical-semantic category of contrast in the financial and economic media discourse (on the material of Englishlanguage Internet sources)] (Doctoral thesis). Retrieved from https://dlib.rsl.ru/viewer/01005555035\#?page=1 (in Russian). 